\title{
Mortgage, Pledge and Charge Transactions in Nige ria: Comparative/Distinctive Analysis and Legal Examination
}

\author{
Malachi Elisha Brown, LL.M, PhD \\ ChiefConsultant, Alfred Chambers (Barristers and Solicitors) 1st Floor, Debo Plaza, 2-4 FGGC Road, \\ Abuloma Town, Port Harcourt, Rivers State, Nigeria \\ and \\ Augustine Evangel Esq, LL.M \\ Principal Lecturer in Law, School Of Foundation Studies, Rivers State Polytechnic, P.M.B. 20, Bori, \\ Rivers State, Nigeria
}

\begin{abstract}
This study is both a comparative analysis and legal examination of various legal terms (mortgage, pledge and charge) usable in contractual and business transactions today. It examines their different types, rights of the parties in such transaction, the English laws regulating such transaction and how these laws have specifically been applied or adopted in Nigeria and Ghana, including other West African countries. It observed that these legal terms are acceptable forms of secured credits by companies, individuals and businesses. It concludes that the mode of security to be adopted by parties in each transaction depends on them and the dictates of circumstances. The importance of these secured credits cannot be over-emphasized in all business or contractual transactions amongst parties (be it companies, management and business ventures).
\end{abstract}

\section{Introduction}

Where one person lends money to another, he may be satisfied with the consequent personal obligation of the debtor to repay the loan and upon default sue for the money. In many cases, the lender requires security transcending the mere personal obligation of the debtor to repay the loan. As a result, the creditor is granted rights over a tangible or intangible asset of the debtor or of a third party. This real security may come in the form of a mortgage, charge or pledge.

Where a lender has real security for his loan, his claim is superior to that of unsecured creditors in the event of the debtor's insolvency. In other words, as regards the property appropriated to the contract of security, the secured lender has preferential rights (Snell, p. 385).

A contract to secure a loan is consensual in nature and unilateral actions by a creditor again st the assets of the debtor do not create a security interest in favour of the creditor. The contract of security confers on the creditor a right in personam and a right in rem. The right in personam is inter partes and imposes on the debtor a personal obligation to repay the loan which obligation does not depend on the existence of the security for its life. Thus, if for any reason the security becomes non-existent, the debtor's personal obligation to repay the loan is not thereby extinguished (Ibid at p.3).

The proprietary right acquired by the creditor in the property earmarked to guarantee the loan is in rem because it can be asserted against all third parties.

Stemming from the types of real securities (pledge, mortgage and charge) in business or contractual transactions, we shall now examine them seriatim.

\section{PLEDGE: DEFINITION}

A pledge is a kind of indigenous mortgage by which the owner-occupier of land in order to secure the advantage of money or money's worth gives possession and use of the land to the pledge creditor until the debt is fully paid or discharged (Adjei v. Dabanka (1930) W.A.C.A. 63 at 66-67.

A pledge is thus a security transaction in which land is given as security for the sum borrowed. Before a transaction can qualify as a pledge, possession and use of the land in question must be given over to the pledge. Dealings in land which do not incorporate this characteristic can not rightfully be described as pledges. Nor is a dealing in land automatically a pledge because of the transfer of possession and use of the land in question to one of the parties (The Question of Accountability in the Customary Law Pledge" (1978) J.A.L. 125 at 129). It is appropriate for the repayment of a debt or the performance of an obligation.

The pledgee enters into possession of the land holding it as security and uses the said land as so me sort of interest on the amount borrowed or as mesne profit on the article or goods given on credit. The pledgee also takes possession so that his profiting from the land may compel the pledgor to redeem the land. Essien, p. 59).

\section{TYPES OF PLEDGE}

(a) Traditional Pledge 
This type of pledge is perpetual in nature and remains a pledge until redeemed. The right of redemption is not affected by the effluxion of time. In this type of pledge, the pledge enjoys the yields of the land unconditionally until the land is redeemed (Ibid at p. 60).

(b)

\section{Term Pledge}

The term pledge lasts for a period agreed by the parties to the pledge and determines upon the expiration of the said period or term. Upon reasonable notice given to the pledgee, the pledgor can redeem at any time even before the term effluxes (Ibid at p.60).

\section{Self-Redeeming Pledge}

In a self-redeeming pledge, the pledgee enters into possession and uses the land, the yields therefrom being applied to the repayment of the loan or discharge of the obligation or which the land was appropriated such that the land pledged redeems itself.

The sort of pledge to be adopted is a matter of consensus between the parties.

\section{RIGHTS OF THE PARTIES}

\section{(a) Rights of the Pledgee}

It has already been mentioned that the pledge has the right to possession and use of the land pledged and generally does not have to account for his use and enjoyment of the land since such use is viewed as his interest on the money for which he should not account (Olawoye, p. 129).

However, in proper cases, the court will seek an account of the pledgee's use and enjoyment of the land. This will be where the pledge has commercially exploited the land (Okoiko v. Esadalue (1974) N.M.L.R. 337). A pledgee may be taken to have commercially exploited the land where the profit he has made therefrom is highly disproportionate to the amount lent and for which the land was pledged. It has been submitted that in cases such as this, it is better for the pledgor to redeem without repaying the borrowed sum than to demand an account from the pledge (Essien E.E., op cit. at p. 212). The reasoning is that a pledgee who knows he will not be called upon to account will develop the pledged land maximally with positive macro-economic effects. The essence of calling for an account is to order that the pledgor be compensated by the pledgee if the court considers this necessary.

The pledgee has a duty to account in a self-redeeming pledge so that the point at which the pledgor regains possession may be more easily determinable. It has already been mentioned that the pledge is redeemed when the yields from the land have repaid the borrowed sum.

Again, the pledgee may sub-pledge the land or assign his interest therein to a third party. This right is exercised upon a request for the repayment of the pledge price being made and not met (Ibid at p. 213). Meek (p. 204) assert that the amount for which the land is sub-pledged should not be higher than the original pledge sum. This position unarguably preserves the pledgor's right of redemption.

There are divergent views on whether the consent of the original owner-pledgor is required for the subpledge (Chubb, p.30). Essien (p.14) observed that sub-pledging without the owner-pledgor's consent may lead to difficulties.

A pledge may also assign his entire term to a third party who substitutes for the pledge and becomes the new pledge to the original owner-pledgor. It has been reasoned that because the pledgee is relinquishing his entire interest in the pledged land to the assignee, an assignment may require the Governor's consent (Ibid at $\mathrm{p}$. 213), which consent may not be required for a sub-pledge being a transaction within the original pledge which had already received the Governor's consent.

The pledgee's right to grant tenancies is subject to the pledgor's right of redemption. Thus the pledgee's exercise of this right does not detract from the pledgor's right to redeem the pledged property (Ibid at p. 215).

\section{Rights of the Pledgor}

The pledgor has the right to redeem the pledged land upon repayment of the amount borrowed. The pledgor is at liberty to redeem the pledged land at any time and this right may not be clogged or fettered by the pledge in any manner.

The pledgee may not develop the land in such a way that will put it beyond the redemption of the pledgor. Customarily, land is redeemable at the same rate at which it was pledged. It has been held that the pledgor is under no obligation to compensate the pledgee for improvements to the pledged land (Amao v. Adigun (1957) W.R.N.L.R. 55).

Customary law however allows a tenant to harvest annual crops before the redemption. Accordingly, reasonable notice of intention to redeem is required of the pledgor (Essien, p.30). Hill (p.17) observed that the 
right to redeem is perpetual and the courts have allowed redemption after a period of about sixty years had elapsed (Kofi v. Kofi (1933) W.AC.A 284). The right to redeem is no longer perpetual in Ghana, by virtue of Section 30(3) of the Limitation Decree 1972 (N.R.C.D. 54).

\section{REALISATION OF PLEDGE}

Since the rule is that a pledge is perpetually redeemed, it may safely be said that a pledge is a security that is not realizable.

Remedies like foreclosure and power of sale available to mortgagees do not avail pledges. The pledgee may not sell the property since he has only possession and not title. The maxim is Nemo Dat Quod Non Habet.

However, the pledge agreement may confer a right of sale expressly on the pledge (Nwabueze, p.20). The basis of this, is contractual since it is not allowed in customary law. Apart from the possibility of acquiring a contractual right of sale, the pledgee's right to sub-pledge or assign his entire term appears to be the closest he can come to realizing his interest in the land pledged.

\section{Mor tgages: Definitional Concept And Meaning}

Waldock (p.37) view mortgage as a conveyance of land or an assignment of chattels as a security for the payment of a debt or the discharge of some other obligation for which it is given. This definition was supported by Lindley M.R. in the British case of Santley v. Wilde (1899) 2 ch. 474 (C.A.). Essien (p.41) observed that this definition raise difficulties in the Nigerian context since "conveyance" entails passing title which is not applicable in Nigeria. A more appropriate definition is to be found in Section 1(1) of the Ghanaian Mortgages Decree, thus:-

A mortgage for the purposes of this Decree is a contract charging immovable property as security for the repayment of a debt and interest accruing thereon or for the performance of some other oblig ation for which it is given, accordance with the terms of the contract.

It seems clear that a mortgage may not always be for the purpose of securing a debt; it may also be used to secure some other obligation. At common law, a mortgage was a conveyance of land which on the face of it was absolute and conveyed a fee simple estate but which was in fact conditional. The difficulty with this arrangement was that the lender was the absolute owner of the property and could sell, refuse to reconvey or deal in any manner with the property as he deemed fit.

This difficulty prompted the courts of equity to increasingly protect the borrower's interest such that a borrower could insist on reconveyance on redemption. This greatly watered down the hitherto wide powers of the lender over the property mortgaged. At a point the lender was absolute owner in theory, but had few of the practical rights of ownership. This situation was seen in many jurisdictions as artificial and was statutorily. Law of Property Act 1925, altered the situation so that the mortgagor would retain ownership and the mortgagee's rights would be protected. Such as foreclosure, power of sale and right to take possession.

Accordingly, the practice now is that the mortgagor remains the legal owner of the property but the creditor gains sufficient rights over it to enable him enforce his security.

\section{TYPES OF MORTGAGE}

(a) Legal Mortgage: This type of mortgage include the discussions contained in the conceptual definitions and meanings that has been given above.

(b) Equitable Mortgage: These are contracts which operate as security and are enforceable under the equitable jurisdiction of the court (Tyler and Lightwoods, p.42). These contracts may arise where the ingredients thereof are not sufficient to constitute a legal mortgage.

\section{Creation Of Mortgages}

Before the Land Use Act, legal mortgage of freehold land was created by conveying the fee simple estate to the mortgagee with a proviso for a reconveyance on redemption. Since the mortgagor conveyed his entire legal interest in the land, subsequent mortgages were necessarily equitable, The mortgagor could subsequent upon such a legal mortgage only mortgage his equity of redemption.

A legal mortgage of a leasehold land was by a sub-demise or an assignment. In an assignment, the mortgagor transfers the residue of his term to the mortgagee and is left with the legal right of redemption. In sub-demise, the term transferred is slightly shorter than the residue of the mortgagor's term leaving the latter with a right of reversion (Waldock, p.31).

Equitable mortgagees were created by a contract to create a legal mortgage which was defective in form for any reason. They also arose where there was an agreement to create a legal mortgage in future. Before the courts will decide for an equitable mortgage in the two situations above, the agreement must be in writ ing and signed or there must have been part-performance or some other consideration provided by the mortgagee. 
An equitable mortgage may be created by the mortgagor relinquishing his equitable interest in a property to the mortgagee. This may arise where for instance he had earlier conveyed his whole legal interest in the property to a prior mortgagee. There is usually a provision for reassignment on discharge of the debt. The mortgage has to be by deed or evidence in writing (Section 3 of the Statute of Frauds).

Where title deeds are deposited by a borrower with the intention that they be held as security for the loan; the courts will hold that there was an equitable mortgage. The deposit of title documents is construed as part-performance thereby taking the transaction outside the ambit of the Statute of Frauds and rendering evidencing the transaction by writing unnecessary (Mcbride v. Sandland (1919) 25 C.L.R. 69 at 78 ; Ex Parte Haigh (1805) 11 ves. 403).

If title deeds are deposited without disclosure of intention, the courts lean towards an equitable lien instead of an equitable mortgage. It is thus the practice to evidence such intention with a memorandum signed by both parties (Section 2 of the Law of Property (Miscellaneous Provisions) Act).

In the states of the former western Nigeria which applied the Property Conveyancing Law 1959, a legal mortgage of freehold land was created either by demise for a term of years absolute subject to a provision for cesser on redemption or by a charge by deed expressed to be by way of legal mortgage (Section 108 of the Property and Conveyancing Law, 1959).

Further, Section 108(2) of the Property Conveyancing Law converted pre-1959 mortgages which were by conveyance of the fee simple into de mise for 3000 years was also adopted as the normal mortgage term since Section 108(1) did not specify the number of years for which a demise of freehold should run. Under the Property and Conveyancing Law, subsequent mortgages could be legal since the mortgagor did not transfer his entire legal interest in the land to the mortgagee.

By Section 110(1) of the Property and Conveyancing Law,1959, a mortgage can be created by a charge by way of legal mortgage. This combined the simplicity of the charge with the advantages of a legal mortgage. A mortgage of this nature embodies the same powers and remedies as a legal mortgage.

The deed should state that the charge is by way of legal mortgage. The legal charge does not convey any propriety right to the chargee and the mortgagor retains full title rather than a nominal reversion as in a demise, whereas a mortgage conveys proprietary interest to the mortgage, a charge creates such rights in the chargee (Essien E.E. op.cit. at 161).

Leasehold interests were mortgage interests mortgaged either by a sub-demise for a term of years absolute less than the term vested in the mortgagor and subject to a provision for cesser on redemption or by a charge by deed expressed to be by way of legal mortgage, Section 109(1) Property and Conveyancing Law 1959. Sub-demising a term less than the mortgagor's term enabled him to retain his reversion and also create successive legal mortgages.

Creating a legal mortgage by charge over a leasehold was done in a similar as for a freehold. Equitable mortgages of freeholds and leaseholds were created in the same way as in the unamended common law state.

In the parts of Lagos under the Registration of Titles Act, mortgages of freehold and leasehold land was by charge and similar to the charge by deed by way of legal mortgage as in the Property and Conveyancing Law states. Under the Registration of Tit les Act, equitable mortgages could be created by depositing the certificate of title with the intention of mortgaging his land or charge. The deposit has to be registered as an encumbrance on the land within two months of the deposit and mortgage by deposit may be forbidden at the time a certificate is issued (Sections 58(2) and 58(4) of the Registration of Titles Act).

Again, where someone fails to register a charge as required by the Registration of Titles Act, an equitable mortgage arises since the conveyance of the legal estate thereby fails.

\section{CREATION OF MORTGAGES UNDER THE LAND USE ACT}

Under the Land Use Act, mortgages may be created in any of the following ways:-

1. By assignment of the unexpired term of the right of occupancy as evidenced by the certificate of occupancy subject to re-assignment on redemption.

2. By a sub-demise of a term shorter than the mortgagor's whole term to the mortgagee subject to cesser on redemption.

3. By a charge by deed expressed to be by way of legal mortgage.

In the states under the unamended common law, the first two methods are used by the length of assignment or sub-demise depending on whether the right of occupancy being mortgaged is a granted or statutory right. In the former, the term is stipulated in the certificate of occupancy; in the latter, the duration is indefinite.

The Act preserves the pre-Act conveyancing laws subject to such additions, alterations or omissions as will bring them into conformity with this decree or its general intendment (Section 48, Land Use Act) 
Equitable mortgages are still created in the same manner in which they were created before the Act. By Sections 21 and 22 of the Land Use Act, the Governor's consent is required for the creation of a mortgage. Mortgage of family or communal land requires the consent of the head and principal members of the family or community. Determining the head and principal members of a family or community is a question of fact (Esan v. Faro (1947) 12 W.A.C.A. 135).

\section{Rights Of The Mortgagee}

(a) Custody of Mortgage Deeds: The mortgage has the right to custody of the title deeds provided the mortgage is not by way of sub-demise for here the mortgagee will be like a sub-tenant who is not entitled to title deeds except such a right is expressly stipulated in the deed. Waldock, op. cit. at p. 23.

Under the Property and Conveyancing Law, whether the mortgage be by assignment or sub-demise the mortgagee is entitled to custody of the title deeds. Equitable mortgagees have no right to custody of the title deeds unless such right is stipulated in the agreement.

\section{Right To Possession Of The Mortgaged Property}

If the mortgagee does not contract himself out of this right, he may take possession the moment the mortgagee is executed (Harman J.in Four Maids Ltd v. Dudley Marshall (properties) Ltd (1957) ch. 317 at 320). As a result of the intervention of equity, such as insisting on the mortgagee accounting for his passion, mortgagees are no longer inclined to take possession except as a means of obtaining vacant possession so as to deliver vacant possession to a purchaser should the mortgagee exercise his power of sale (Hughes v. Waite (1957) 1 W.L.R. 713 at 715).

The right of possession does not avail an equitable mortgagor since he has no legal right to the property (Barclays Ltd.v. Bird (1954) ch. 274 at 280), except such right be conferred on him by the agreement.

\section{Right To Lease}

The mortgagee who is in possession can lease the mortgaged property to third parties. An equitable mortgagee does not have this right. The legal chargee has statutory power to grant leases (Sections 121(2); 8(1) of the Property and Conveyancing Law, 1959). The mortgagee's right to grant leases may be contractual or statutory.

Where the mortgagee is not in possession, the power of the mortgagor to grant leases of the mortgaged property is restricted by, for instance, requiring the consent of the mortgagee to any lease. If the mortgagor grants a lease without the consent of the mortgagee, the lease does not bind the mortgagee but is binding as between the mortgagor and the lessee. In this regard, the mortgagee can eject the tenant since his title is paramount to that of the mortgagor (Waldock, op. cit. at p. 217). If the mortgagor adopts the lease, he is bound by it (Chartsworth Properties Ltd v. Effiom(1971) 1. W.L.R. 144).

\section{RIGHT TO INS URE}

Upon execution of the mortgage, the mortgagee has a statutory right to insure the property and the premiums thereby arising shall be a charge on the mortgage debt (Section 123(1) of the Property and Conveyancing Law, 1959).

Except otherwise provided by the agreement, the amount of insurance should not exceed two-thirds of the amount that would be required to restore the property in the event of destruction (Section 130(1) of the Property and Conveyancing Law, 1959). The amount of insurance should conform with the amount specified in the deed.

\section{RIGHT TO PRESERVE THE PROPERTY}

Arising from his legal or equitable interest in the land, the mortgagee has the right to preserve the property and he may restrain subsequent encumbrancers from dealing prejudicially with the property (Legg $\mathrm{v}$. Matheson (1860) 2 Giff 71).

\section{RIGHTS OF THE MORTGAGOR}

(a) Right to Lease: Just like the mortgagee, the mortgagor has the right to lease the mortgaged property provided he is in possession which is normally a question of agreement with the mortgagee in whom he vests the right to possession.

(b) Right to Redemption: Whether the mortgage is equitable or legal, the mortgagor has the right to redeem the property as soon as the mortgage is created. The practice is to postpone the exercise of this right for a reasonable time. In some deeds, the date of redemption is fixed by the parties. If the contractual redemption date is unconscionably far in the future, the right to redeem arises after a reasonable time. 
In Fairclough v. Swan Brewery Co (1912) A.C. 565, it was held that the postponement of the right to redeem a mortgage for a twenty-year lease until six weeks before the expiration of the term was void because it effectively prevented redemption, as it was "oppressive and unconscionable".

It may be noted that whether the postponement of the right to redeem is valid or unconscionable is a question of fact.

(c) Right to Sale: The mortgagor has a statutory right to sell the mortgage property In Section 25(1) of the Conveyancing Act; Section 114(1) of the Property and Conveyancing Law; and Section 91 of the Law Property Act, even after the mortgagee's right of sale has arisen so long as the mortgagee has not exercised the right, the mortgagor has to apply to court for an order of sale (Brewer v. Square (1892) 2 ch. 111).

\section{REALISATION OF MORTGAGE.}

(a) Sale: The mortgagee may realize his security by a sale of the mortgaged property. At common law, this power was hardly in existence since the mortgagor's equity of redemption still subsisted even after the mortgagee had exercised his power of sale. The mortgagee could avoid this only by applying to court for a judicial order of sale which order extinguished the mortgagor's equity of redemption.

This difficulty led mortgagees to prefer the insertion into the agreement of an express power of sale such that on failure of redemption, the mortgagee may lawfully sell the property. This power of sale may also be statutory (Section 19(1) of the Conveyancing Act 1881; Section 101(1) of the Law Property Act, 1925; and Section 123(1) of the Property and Conveyancing Law 1959). Although this statutory power can be excluded by the parties in any business transaction or contract. The power of sale may not be exercised unless the mortgage debt has become due and a three-month notice requiring payment has been served on the mortgagor.

The requirement for a three-month notice will be dispensed with if some interest under the mortgage is in arrears and unpaid for two months after becoming due, or the mortgagor is in breach of some other provision of the mortgage other than the provision for repayment (Section 125 of the Property and Conveyancing Law., 1959; S.20 of the Conveyancing Act, 1881; and Section 103(1) of the Law Property Act, 1925).

It is to be noted that the conditions above are alternative and if any of the lapses occurs, the mortgagee may sell without a three-month notice. The parties may dispense with the need for a three-month notice and agree that the mortgage money be paid on demand within a reasonable time (Fisher and Lightwoods Law of Mortgages op. cit. at p. 379).

Where the land mortgaged is a customary right of occupancy, the Land Use Act, Section 21 (a)(b). imposes the further condition that the power of sale may not be exercised without the consent of the Governor if the sale is by way of court order under the Sheriff and Civil Process Act. There will be no requirement for consent if the sale is out of court in pursuance of express or statutory powers or where an equitable mortgagee applies for a judicial power of sale.

(b) Appointment of a Receiver: A mortgagee has the power to appoint a receiver. Whether the mortgage is legal or equitable, the parties may expressly empower the mortgagee to appoint a receiver if the conditions specified in the agreement are met.

Further, under Section 19(1) of the Conveyancing Act, 1881; Sections 111 and 123(1) of the Property and Conveyancing Law, the mortgagee by deed has statutory powers to appoint a receiver but this power cannot be exercised until the relevant conditions are met. The conditions are the same as those required for the exercise of the power of sale. The power to appoint a receiver can not be exercised until the power of sale becomes exercisable (Section 131(1) of the Property and Conveyancing Law 1959).

The receiver can only receiver and apply the income from the mortgaged property unless he is expressly given wider powers. He acts as the agent of the mortgagor however appointed (whether expressly, by agreement or statutorily).

Where the court finds it just and convenient so to do, a receiver is appointed on the application of one or more mortgagees (Section 25(8) of the Judicature Act 1873). The court-appointed receiver is an officer of the court and has personal liability for his actions and inactions.

Where nothing is likely to be recovered from the property, the court will hesitate to appoint a receiver.

\section{FORECLOS URE}

This is the judicial process by which the mortgagor's right to redeem is extinguished and the property fully becomes hat of the mortgagee. Foreclosure can only be done by the courts. Foreclosure is available to all types of mortgagees. The courts initially grant an order nisi ordering that all relevant accounts be taken to ascertain what is due to the mortgagee. After this, a six-month period lapses before the order is made absolute.

A foreclosure order absolute may be reopened at the discretion of the court. Again, it will be reopened if the mortgagor comes promptly. If the property has not been sold after foreclosure and the mortgagee sues the 
mortgagor on his personal obligation to repay, foreclosure will be reopened. The mortgagee can not hold onto his security and still sue on the mortgagor's personal promise to pay.

The courts are statutorily empowered to order a sale upon an application for foreclosure (Section 25(2) Conveyancing.Act 1881; Section 114(2) Property and Conveyancing Law 1925; and Section 91(2) of the Law Property Act 1925).

\section{CHARGE: DEFINITIONAL TERMS AND MEANING}

A charge encumbrances the debtor's property in favour of the creditor such that the latter can pursue remedies against the property and not merely the debtor in the event of default by the debtor in repaying the debt.

The creditor is the chargee and the debtor is the chargor. A charge does not pass possession or title to the chargee but it creates rights of a proprietary nature which run with the property such that the chargee can exerc ise it even against a trustee in bankruptcy (Sykes and Walker, op. cit, at p. 18)

\section{CREATION OF A CHARGE}

No special words or formalities are needed to create a charge. It is enough if it can be gathered from the instrument an intention by the parties to use the property in question as security (Craddock v. The Scottish Provident Institution (1893) 69 L.T. 380).

\section{RIGHTS OF THE CHARGEE AND CHARGOR}

The chargee acquires a right to be paid out of the property securing his loan the moment the charge is created. This right resides in him until it becomes realizable. The chargor has the right to unencumber his property by redemption.

\section{REALISATION OF CHARGES}

The chargee may realize his security by sale of the property or the appointment of a receiver. He does not have the right to foreclosure since he has not title to be perfected by a foreclosure order. The chargee may apply to court for an order of sale or for the appointment of a receiver. Where the charge is by deed the chargee has a statutory power of sale and does not need recourse to the courts (Section 123 of the Property and Conveyancing Law 1959; Section 19 of the Conveyancing Act 1881; and Section 101 of the Law Property Act 1925).

\section{MORTGAGE, PLEDGE AND CHARGE COMPARED}

A pledge is basically a customary law transaction. The mortgage is governed by common law and statute with the moderating influence of equity. The charge simpliciter falls largely with in the province of equity but the charge by deed is also governed by statute.

A mortgage is created by strict adherence to the formalities. Where there is any lapse, an intention to create a legal mortgage may end up in the creation of an equitable mortgage. The creation of a mort gage is governed by statute and contract. It would seem that the parties to a mortgage have wide powers to vary, modify, exclude or otherwise deal with the statutory provisions governing mortgages.

The charge requires no formalities or special words for its creation. It is enough if the parties evince an intention to use the property in question as security for the loan. The creation of a pledge requires no particular form. It is usually done in the presence of witnesses and the pledgee provides the customary requirements for the ceremony to mark the creation of the pledge.

Upon creation, a mortgage conveys to the legal mortgagee a legal interest in the property used as security. If the mortgage is equitable, an equitable interest is transferred to the mortgagee. The interest of the mortgagee is proprietary in nature and he may take possession of the property.

The equitable mortgagee may gain right to possession by agreement. However, possession is not of the essence of a mortgage.

A pledge confers the right to possession and use of the land pledged on the pledgee. Whereas the strictures of equity restrain mortgagees from taking possession in practice, pledgees actually take possession and use the land. Indeed, where there is no possession, it casts great doubts on the transaction as a pledge.

A mortgagee who enters into possession has to account for the income from the property. A pledgee generally has no such duty except in exceptional circu mstances.

A chargee does not have right to possession nor is any other right in the land transferred to him. What he has is the right (created in him by the charge) to be paid out of the property charged.

It used to be that a mortgage transferred ownership to the mortgagee which was reconveyed to the mortgagor upon redemption. Today (just like the pledge does not transfer title to land to the pledgee) the 
mortgage does not transfer title to the property to the mortgagee but the latter acquires sufficient rights over the property to secure his loan.

In pledges and mortgages, the right of redemption can not be clogged. The object of both transactions being to secure a debt or obligation and not to transfer ownership of property to the pledge or mortgagee. The right of redemption also avails the chargor.

Apart from having possession and use, the pledgee can sub-pledge, assign or grant tenancies of the land pledged. The mortgagee has pre-enforcement rights in the mortgaged property and may enter into possession, insure, lease, have custody of the title deeds and generally preserve the property mortgaged. The chargee may also preserve the property charged since he looks up to it for the payment of his loan.

The pledge is a security that can hardly be realized. The mortgagee may realize his security by foreclosure, exercise of the power of sale or the appointment of a receiver. The chargee can not foreclose but may apply to court for an order of sale or the appointment of a receiver. If the charge is by deed, the chargee need not resort to court to sell the property charged. Here, he is statutorily empowered to sell.

\section{Conclusion}

The mortgage, pledge, and charge are forms of real security which broaden the options of the creditor beyond reliance on the promise of the debtor to pay. The mode of security to be adopted depends on the parties and the dictates of circumstances. These legal terms are important in all business or contractual transactions amongst parties (be it companies, management and business ventures). There are municipal or domestic laws in various countries to regulate such transactions.

(A) BOOKS

\section{References}

[1]. Chubb L.T ., Ibo Land Tenure (2nd edition),. Ibadan: Ibadan University Press, 1961.

[2]. Essien E.E., Law of Credit and Security in Nigeria. Uyo: Golden Educational Publishers, 2000.

[3]. Goode M.R., LegalProblems of Creditor and Security, London: Sweet and Max well, 1982.

[4]. Hill O., Rural Hausa,. London: Cambridge University Press, 1972.

[5]. Nwabueze B.O., Nigerian Land Law,. Enugu: Nwamife, 1972.

[6]. Obi S.N.C., Ibo Law of Property, London: Butterworths, 1963.

[7]. Olawoye C.O., "The Question of Accountability in the Customary Law of Pledge (1978)" J.A.L.

[8]. Ollenu N.A. and Woodman C.R. Ollenu, Principles of Customary Land Law in Ghana., (2nd edition ed) Birmingham: CAL Press. ISBN 978-0-9510530-0-3.

[9]. Paul Vivian Baker and P. St. J. Langan, Snell's Principles of Equity, 28th edition, Sweet \& Maxwell edition.

[10]. Tyler E.L.G. Fisher and Light woods Law of Mort gages, London: Butterworths, 1988.

[11]. Waldock C.H.M. The Law of Mort gages 2nd edition, London: Sweet and Maxwell, 1950.

\section{(B) DECIDED CASES}

[12]. Adjei v. Dabanka (1930) W.A.C.A. 63 at 66-67

[13]. Amao v. Adigun (1957) W.R.N.L.R. 55

[14]. Barclays Ltd Bird (1954) ch. 274at 280

[15]. Brewer v. Square (1829) 2. ch. 111

[16]. Chat sworth Properties Ltdv. Effiom (1971) 1 W.L.R. 144

[17]. Craddock v. The Scottish Provident Institution (18930 63 L.T. 380.

[18]. Esan v. Faro (1947) 12 W.A.C.A. 135

[19]. Hughes v. Waite (1957) 1 W.L.R. 713 at 715

[20]. Kofi v. Kofi (1933)W.A.C.A. 284

[21]. Legg v. Mathieson (1860) 2. Fiff 71

[22]. Okoiko v. Esadalue (1974) N.M.L.R. 337

[23]. Santley v. Wilde (1899) 2 ch. 474 (C.A)

\section{(C) LEGISLATION}

[24]. Conveyancing Act 1881

[25]. Judicature Act 1873

[26]. Limitation Decree 1972 (N.R.C.D. 54)

[27]. Land Use Act 1978

[28]. Law of Property Act 1925

[29]. Property and Conveyancing Law 1959

[30]. Registration of Titles Act

[31]. Statute of Frauds 